\title{
Adoption of Information and Communications Technology in the Turkish Forest Products Industry: A Case Study
}

\author{
Tarı GEDIK*®, İdris DURUSOY॰ \\ Duzce University, Faculty of Forestry, 81620, Düzce, TURKEY \\ "Corresponding Author: tarikgedik@ duzce.edu.tr
}

Received Date: 01.03.2019

Accepted Date: 11.02 .2020

\section{Abstract}

Aim of study: This study explores the adoption of information and communications technologies (ICTs) and current and potential ICT use in forest products industry. Based on the perceptions of the respondents, the paper investigates the underlying factors affecting the adoption of ICT.

Area of study: Case study is conducted in Düzce province where nearly all types of forest product enterprises are conducting business operates.

Material and method: Face-to-face interviews were conducted with owners and/or engineers of forest products companies. A questionnaire was developed with three main sections, including 20 questions and 81 judgments. Data on the study parameters were coded and analyzed using SPSS software.

Main results: The three major constructs of these factors, based on the purposes of ICT use, were identified as business productivity, information exchange and customer communications. Increased access to current industry news was the principle benefit expected by the respondents from the Internet use, followed closely by enhancement of the company image and facilitation of banking transactions. According to the study, information and communications applications were more common than ebusiness and e-commerce use in the forest products industry.

Research highlights: The forest products industry should plan to develop and implement ICT strategies focusing on increased business productivity, competitiveness and profits, in addition to efficient customer and supplier communications and expanded markets.

Keywords: Purposes of ICT Use, Internet, Factor Analysis, Business Productivity.

\section{Türkiye Orman Ürünleri Endüstrisinde Bilgi ve İletişim}

\section{Teknolojileri Kullanımı: Bir Vaka Çalışması}

$\ddot{O} \mathbf{z}$

Çalışmanın amacı: $\mathrm{Bu}$ çalışma, orman ürünleri endüstrisinde bilgi ve iletişim teknolojilerinin (BİT) benimsenme düzeyi ile mevcut ve potansiyel kullanımını incelemektedir. Makalede katılımcıların algılarına dayanarak, BİT'in benimsenmesini etkileyen temel faktörleri araştırılmaktadır.

Çalışma alanı: Vaka çalışması, hemen hemen her türlü orman ürünü işletmesinin faaliyet gösterdiği Düzce ilinde gerçekleştirilmiştir.

Materyal ve yöntem: Sahipler ve/veya mühendislerle yüz yüze görüş̧me yapıldı. 20 soru ve 81 yargı içeren üç ana bölümden oluşan bir anket formu geliştirilmiştir. Çalışma parametreleriyle ilgili veriler SPSS yazılımı kullanılarak kodlanmış ve analiz edilmiştir.

Temel sonuçlar: BİT kullanım amaçlarına göre; işletme verimliliği, bilgi alışverişi ve müsşeri iletişimi olarak tanımlanan üç faktörlü yapı belirlenmiştir. Katılımcıların internetten beklediği temel fayda mevcut endüstri haberlerine erişimin artması olup, ardından şirket imajının iyileştirilmesi ve bankacılık işlemlerinin kolaylaştırılması faydaları gelmektedir. Çalışmada, orman ürünleri endüstrisinde bilgi ve iletişim uygulamalarının, e-işletme ve e-ticaret kullanımından daha yaygın olduğu belirlenmiştir.

Araştırma vurguları: Orman ürünleri endüstrisi, etken müşteri ve tedarikçi iletişimi ile genişleyen pazarlara ilaveten, daha yüksek işletme verimliliăgi, rekabet gücü ve kârlara odaklanan BİT stratejileri geliştirmeli ve uygulamalıdır.

Anahtar Kelimeler: BİT Kullanım Amaçları, İnternet, Faktör Analizi, İşletme Verimliliği

\section{Introduction}

Information technology, or its broader synonym- information and communications technology (ICT), is commonly defined as the hardware, software, networks, and media used for collection, storage, processing, 
transmission, and presentation of information (World Bank, 2002). The OECD (2011) defines the ICT sector as encompassing the manufacturing and services industries that capture, transmit, and display data and information electronically. The emergence of ICT in the last two decades has radically shifted the paradigms of business interactions and operations. The rapid growth of ICT is altering both individual and business life. ICTs offer small and large businesses new opportunities for communicating, knowledge sharing and developing their trade.

Because ICT is regarded as the key to flexible organizations (Levy \& Powell, 1998), SMEs are forced to adopt these technological changes in order to enhance their competitive advantage (Nguyen, 2009). The SMEs fall behind the larger businesses in the adoption of ICT due to their limited financial and skilled human resources (Riquelme, 2002; Lee, 2004).

The forest products industry has adopted ICT more slowly than most sectors, even in the countries where it constitutes a key exporting sector (Karuranga et al., 2006; Sowlati, 2014). When the Internet was just beginning to gain popularity, the forest products industry used it primarily for accessing industry-level databases and information (Vlosky \& Gazo, 1996). Later surveys of the forest products industry indicated that companies had started to use the Internet for customer communication and product promotion (Vlosky \& Fontenot, 1997; Vlosky, 1999). Although forest product exporters (Pitis \& Vlosky, 2000a; Pitis \& Vlosky, 2000b), larger companies (Dupuy \& Vlosky, 2000) and companies producing higher-value products (Kozak, 2002) were early adopters of ICT, they used it mainly for promotional benefits.

A thorough review of ICT adoption in the forest products industry (Hewit et al., 2011) revealed that a majority of the companies were in the virtual and communication spaces of the evolutionary model of Internet business strategies (Angehrn, 1997), while relatively few of the companies had evolved into the distribution and transaction spaces, where companies use ICT for e-business or e-commerce, supply-chain management and financial transactions (Stennes et al., 2006;
Hewit et al., 2011). Widespread uses of ICT in the forest products industry include mostly lower-order technologies like e-mail and static websites (Shook et al., 2002; Arano \& Spong, 2012).

The province of Düzce is a one of the leading producers of forest products in Turkey. Nearly all types of forest product enterprises are conducting business in Düzce Province, thus making Düzce a suitable study area for this research.

This study aimed to explore the level of adoption of information technologies in the forest products industry in Turkey. The study investigates the factors affecting the use of computers and the distribution of the Internet among forest industry companies in a particular geographical region of Turkey. Accordingly, this study mainly focuses on the analyses of: (i) the main characteristics of forest products companies; (ii) the ownership and the uses of computers and internet in these companies; (iii) the factors affecting the adoption of ICT; and (iv) the expectation of companies for the adoption of ICT.

\section{Materials and Methods}

The study population included 241 forest products companies registered with the Düzce Chamber of Commerce and Industry, from whom the names and addresses of the companies surveyed were obtained.

The minimum sampling size was calculated as 68 using sample size formula, with a confidence level of $95 \%$ and a sampling error of $10 \%$ (Lemeshow et al., 1990).

$$
\mathrm{n}=\left(\mathrm{Z}^{2} \cdot \mathrm{N} \cdot \mathrm{P} \cdot \mathrm{Q}\right) /\left(\mathrm{N} \cdot \mathrm{D}^{2}+\mathrm{Z}^{2} \cdot \mathrm{P} \cdot \mathrm{Q}\right)
$$

Where $\mathrm{n}=$ sample size, $\mathrm{z}=$ level of confidence $(95 \%), \mathrm{P}=0.5, \mathrm{Q}=1-\mathrm{P}, \mathrm{d}=$ margin of error (10\%).

Organizational informants including owners and engineers were contacted personally. Face-to-face interviews were conducted with owners and/or engineers. A questionnaire was developed with regard to previously validated studies (Tan et al., 2004; Kılıç, 2008; Yıldız, 2008). The questionnaire included four sections pertaining to (1) the selected features of the companies, (2) internet use, (3) purpose of ICTs, and (4) 
perceived benefits of ICTs. In addition to multiple choice and open ended questions, respondents were asked to rate perceived benefits from Internet use, purposes of ICT use, features and services ICT could provide for their companies (5-point scales). Data on the study parameters were coded and analyzed using SPSS software.

In order for a questionnaire be valid, it must measure what it is intended to measure. Factor analysis was used for the justification of the construct validity. The Kaiser-MeyerOlkin test was applied to check the adequacy of the data set for running the factor analysis. The Bartlett's test of sphericity was used to examine the hypothesis that the variables were uncorrelated in the population (Sharma, 1996). The Kaiser-Meyer-Olkin Measure of Sampling Adequacy and a highly significant Bartlett's test of sphericity $\left(\chi^{2}=738.000 \mathrm{p}<\right.$
0 .) indicated that the correlations between the items were large enough to perform a factor analysis. The reliability of the scale was evaluated by the Cronbach's alpha coefficient. The Cronbach's alpha of the scale was 0.9465. Acceptable alphas can range from 0.60 to 1.00 ; thus, the scales in this study were highly reliable.

\section{Results}

Characteristics of the Respondent Companies

The 68 respondents included managers or engineers (55.9\%), company owners (30.9\%) and shareholders $(13.2 \%)$. Of the companies, $36.8 \%$ were incorporated, $30.9 \%$ limited, $16.2 \%$ unlimited and $10.3 \%$ open, while $5.9 \%$ of the companies did not declare their status.

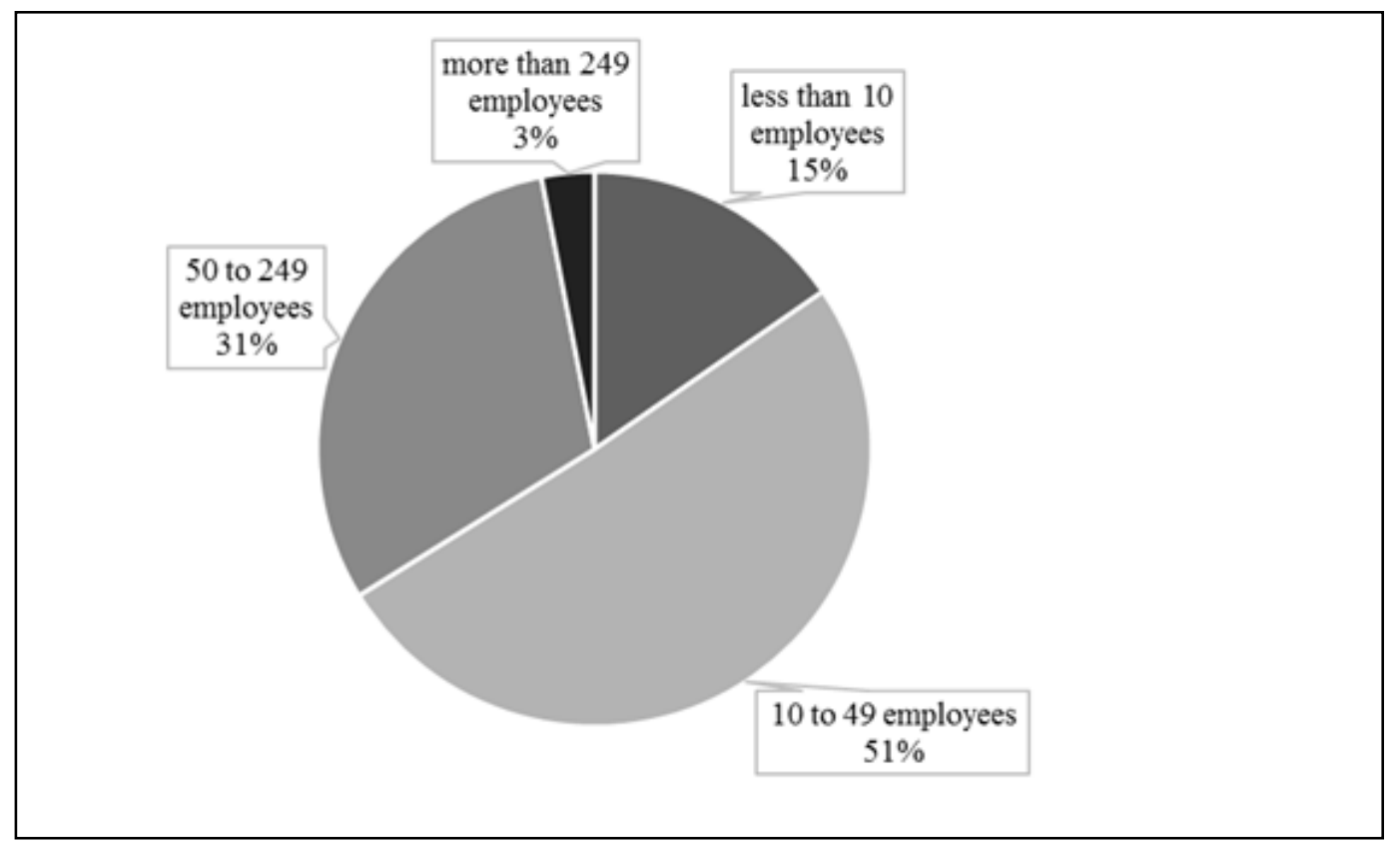

Figure 1. Employment in surveyed Turkish forest products companies

The oldest of the companies was founded in 1935, while the youngest was established in 2009. The number of employees in the companies surveyed ranged between 2 and 340. One third of the respondent companies were small, with fewer than 50 employees per company (Figure 1) and most companies had been in business for more than 10 years. Figure 2 shows the percent of respondents manufacturing primary and secondary products. Furniture was the highest ranked product, with $35 \%$, followed by wood products $(26 \%)$, lumber $(19 \%)$, and veneer and plywood (15\%). 


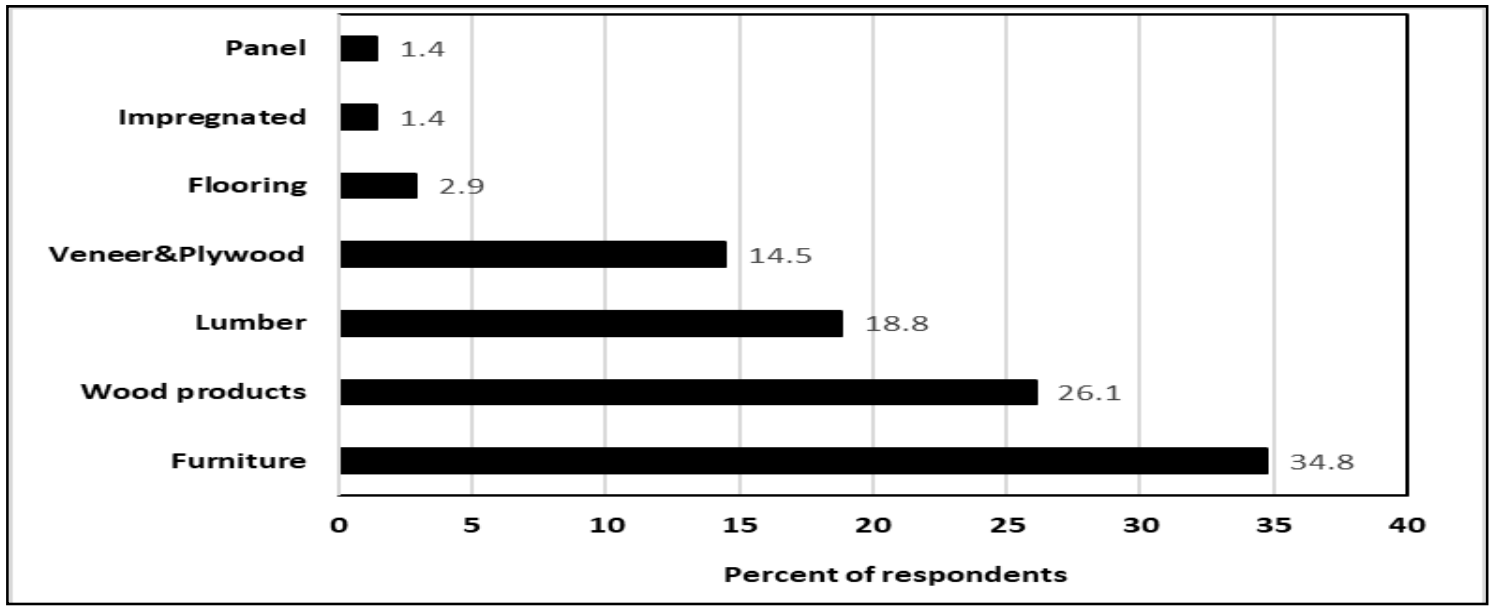

Figure 2. Production by product type in surveyed Turkish forest products companies (\% of respondents)

The companies were asked their reasons for operating in the forest products industry. The stated incentives for investing in forest products included the increasing demand for forest products, profit margins, promptness of distribution, transportation and input (raw material and labor) and the relatively lower costs of raw materials.

The participating companies were operating at many different locations, with $33.8 \%$ in organized industrial zones and $13.3 \%$ on small industrial sites, while $52.9 \%$ operated outside the boundaries of any industrial zones or sites. The majority of the companies $(61.8 \%)$ reported exporting forest products. When asked where they procured their raw materials, they reported various combinations of domestic and foreign locations, with $59 \%$ procuring from mixed local, regional and foreign sources, $29 \%$ only from domestic channels, $13 \%$ from local sources only, while another $16 \%$ used regional sources and $10 \%$ of the companies acquired raw materials solely from foreign countries.

Computer and Internet Use in the Forest Industry

An overwhelming majority of the forest industry companies surveyed (57 of 68) used computers. All of the companies having computers also used the Internet. The number of computers in the company ranged between 1 and 75, depending on company size. In all the companies surveyed, the average number of computers being used was eight. The Turkish Statistical Institute (TÜIK, 2014) reported that the proportion of enterprises using the Internet in Turkey in 2013 and 2014 was, respectively, $92.0 \%$ and 94.4\% (Table 1).

Table 1 . Use of ICT by enterprises in Turkey

\begin{tabular}{lccccc}
\hline & $2010(\%)$ & $2011(\%)$ & $2012(\%)$ & $2013(\%)$ & $2014(\%)$ \\
\hline Computer usage & 92.3 & 94.0 & 93.5 & 92.0 & 94.4 \\
\hline Internet access & 90.9 & 92.4 & 92.5 & 90.8 & 89.9 \\
\hline Web page ownership & 52.5 & 55.4 & 58.0 & 53.8 & 56.6 \\
\hline
\end{tabular}

The results indicated that there was a significant relationship $(r=0.713 ; p<0.05)$ between company size and computer and Internet use. Companies with more employees were more likely to use computers and the Internet than companies with fewer employees. However, the age of the company was found to be negatively correlated $(\mathrm{r}=-0.536 ; \mathrm{p}<0.05)$ with computer and Internet use. Older companies were less likely to use computers and the Internet. 
A majority (82.5\%) of all respondents reported having a web page. Of these, $94.2 \%$ felt their web page reflected the firm's features, while $5.8 \%$ did not. A recent national survey (TÜIK, 2014) revealed that $56.6 \%$ of the enterprises in Turkey had their own web page. Web page ownership in the surveyed Turkish forest products companies was above the national average (Table 1). These results indicated that there was a significant relationship $(r=0.509 ; p<0.01)$ between web page ownership and export. Exporting companies were more likely to have a corporate web page.

To explore the role of the Internet in business communications, the respondents were asked how they made their communication for business documents (Table 2). Hand delivery was by far the preferred method for the companies surveyed to transmit business documents, including those for transportation, official business, accounting and customs. Private mail was the apparent choice of companies for invoices, followed by hand-delivery. E-mail was preferred for advertising, orders and other documents. Taxation documents were commonly transmitted by hand-delivery, followed closely by e-mail. Faxes were most commonly used for orders.

Departmental use of the Internet was examined in the study. Nearly all departments used the Internet for various purposes. In forest products companies, the most extensive use of the Internet was in accounting departments (89.7\%), followed by production $(88.2 \%)$, human resources (85.3\%), purchasing (82.4\%), marketing (77.9\%), inventory $(77.7 \%)$, engineering (75\%) and research and development (72.1\%). The length of time the Internet had been used in the forest products companies varied between 1 and 15 years, depending on the age of the company. The average duration of Internet usage time for the surveyed companies was seven years.

Table 2. Methods of transmitting business documents

\begin{tabular}{lcccccc}
\hline \multirow{2}{*}{$\begin{array}{c}\text { Document } \\
\text { type }\end{array}$} & E-mail & Fax & EDI & $\begin{array}{c}\text { Private } \\
\text { mail }\end{array}$ & $\begin{array}{c}\text { Hand- } \\
\text { delivery }\end{array}$ & Other \\
\cline { 2 - 7 } Invoice & 14 & 14 & 2 & 37 & 30 & 3 \\
\hline Accounting & 21 & 19 & 6 & 14 & 38 & 2 \\
\hline Taxation & 34 & 9 & 13 & 5 & 36 & 3 \\
\hline Advertising & 40 & 17 & 4 & 8 & 26 & 5 \\
\hline Official & 25 & 12 & 5 & 15 & 39 & 4 \\
\hline Customs & 17 & 23 & 2 & 22 & 33 & 3 \\
\hline Transportation & 18 & 15 & 5 & 18 & 39 & 5 \\
\hline Order & 35 & 29 & 3 & 8 & 24 & 1 \\
\hline Other & 30 & 25 & 5 & 10 & 25 & 5 \\
\hline
\end{tabular}

\section{Perceived Benefits and Adoption of ICT}

On a 5 -point scale $(1=$ very desirable, $5=$ not desirable at all), the principle benefit respondents could expect from the Internet was shown to be increased access to current industry news, followed closely by enhancement of the company image and facilitation of banking transactions (Figure 3). Other perceived benefits that respondents expected from the Internet included keeping up with the changes in global markets, monitoring competitors and other sectors, exchanging information with corporate customers and researching product lines. Using two-tail t-tests, the mean scores for all purposes of Internet use were found to be significantly different from the neutral point (3.0) of the 5-point scale at the 0.05 level of significance. The Internet was perceived to be better for every aspect of business, faster delivery and product and service purchasing. On the other hand, the least important perceived benefits involved personnel recruitment and accessing the global market.

Thirty initial factors were used to analyze the purposes of ICT use of the companies in 
the Düzce forest products industry. A factor analysis of the item matrix was used to explore factor clusters. The factor structure obtained through the exploratory factor analysis using the maximum likelihood method and varimax rotation is listed in Table 3.

An important step in performing a factor analysis is to decide the number of factors. Among the criteria, Kaiser's criterion (Kaiser, 1958) and Cattel's scree test (Cattel, 1966) are probably the most widely used. Both criteria are based on the variance accounted for by the factor solution (Tinsley \& Tinsley, 1987). In Kaiser's criterion, all factors with eigenvalues greater than 1.0 are retained. In this study there were three factors in this criterion.

A maximum likelihood factor analysis was performed on the 30 -item matrix. The eigenvalue for the first three factors was $>1$ (ranging from 4.942 to 2.952 ); hence, only three factors were retained in the study. The three distinct constructs generated from the factor loadings of the purposes of ICT use variables included: business productivity, information exchange and customer communications. After rotation, the business productivity, information exchange and customer communications factors explained $29.068,17.726$ and $17.368 \%$ of the total variance, respectively. Thus, all three of these factors explained $64.162 \%$ of the total variance. Items that loaded high on one construct and relatively low on all others were retained. The variables were retained in a factor in which its loadings were greater than or equal to 0.5 . In cases where a variable loaded high on more than one factor, the variable items were dropped. An iterative process resulted in a reduction from 17 items to three distinct clusters of underlying factors with relatively high internal consistency (Cronbach's alpha): (i) business productivity (10 items, 0.926); (ii) information exchange (4 items, 0.832); and (iii) customer communications ( 3 items, 0.918 ). The overall reliability coefficient (17 items, 0.94$)$ indicated a high internal consistency as well. The Kaiser-Meyer-Olkin measure (KMO = 0.86), which was 'great' according to Hutcheson and Sofroniou (1999), verified the sampling adequacy for the analysis. All KMO values for individual items were greater than 0.75 , which is well above the acceptable limit of 0.5 (Field 2013).

Table 3. Factor analysis of the purposes of ICT use

\begin{tabular}{lccc}
\hline & \multicolumn{3}{c}{ Factor } \\
\cline { 2 - 4 } Item & $\begin{array}{c}\text { Business } \\
\text { productivity }\end{array}$ & $\begin{array}{c}\text { Information } \\
\text { exchange }\end{array}$ & $\begin{array}{c}\text { Customer } \\
\text { communication }\end{array}$ \\
\hline Lowering labor costs & $\mathbf{. 8 4 8}$ & .083 & .252 \\
\hline Shortening product delivery time & $\mathbf{. 7 2 9}$ & .041 & .309 \\
\hline Increasing control and audit & $\mathbf{. 6 8 5}$ & .191 & .466 \\
\hline Enhancing the company image & $\mathbf{. 6 5 8}$ & .237 & .354 \\
\hline Improving service quality & $\mathbf{. 6 4 8}$ & .327 & .326 \\
\hline Rapid product development & $\mathbf{. 6 4 5}$ & .229 & .422 \\
\hline Tracking orders & $\mathbf{. 6 2 2}$ & .269 & .250 \\
\hline Finding cheaper raw materials & $\mathbf{. 5 9 8}$ & .247 & .463 \\
\hline $\begin{array}{l}\text { Facilitating information exchange within } \\
\text { the company }\end{array}$ & $\mathbf{. 5 9 4}$ & .377 & -.213 \\
\hline $\begin{array}{l}\text { Helping with fiscal responsibilities } \\
\text { including taxes }\end{array}$ & $\mathbf{. 5 7 3}$ & .319 & .106 \\
\hline Timely satisfying of customer needs & .215 & $\mathbf{. 8 2 9}$ & .126 \\
\hline $\begin{array}{l}\text { Information exchange with corporate } \\
\text { customers }\end{array}$ & .189 & $\mathbf{. 7 0 1}$ & .284 \\
\hline $\begin{array}{l}\text { Information exchange with individual } \\
\text { customers }\end{array}$ & .152 & $\mathbf{. 6 8 1}$ & .198 \\
\hline Monitoring competitors and sector trends & .198 & $\mathbf{. 5 6 1}$ & .314 \\
\hline
\end{tabular}


Table 3 (Continued)

\begin{tabular}{lccc}
\hline & \multicolumn{3}{c}{ Factor } \\
\cline { 2 - 4 } Item & $\begin{array}{c}\text { Business } \\
\text { productivity }\end{array}$ & $\begin{array}{c}\text { Information } \\
\text { exchange }\end{array}$ & $\begin{array}{c}\text { Customer } \\
\text { communication }\end{array}$ \\
\hline Lowering customer communication costs & .365 & .278 & $\mathbf{. 7 8 4}$ \\
\hline Gathering customer feedback & .280 & .388 & $\mathbf{. 7 4 6}$ \\
\hline Maintaining customer communications & .412 & .436 & $\mathbf{. 6 5 5}$ \\
\hline Eigenvalues & 4.942 & 3.013 & 2.952 \\
\hline$\%$ of variance & 29.068 & 17.726 & 17.368 \\
\hline$\alpha$ & 0.925 & 0.832 & 0.918 \\
\hline
\end{tabular}

Extraction Method: Maximum Likelihood. Rotation Method: Varimax with Kaiser Normalization. Factor loadings over 0.5 appear in bold

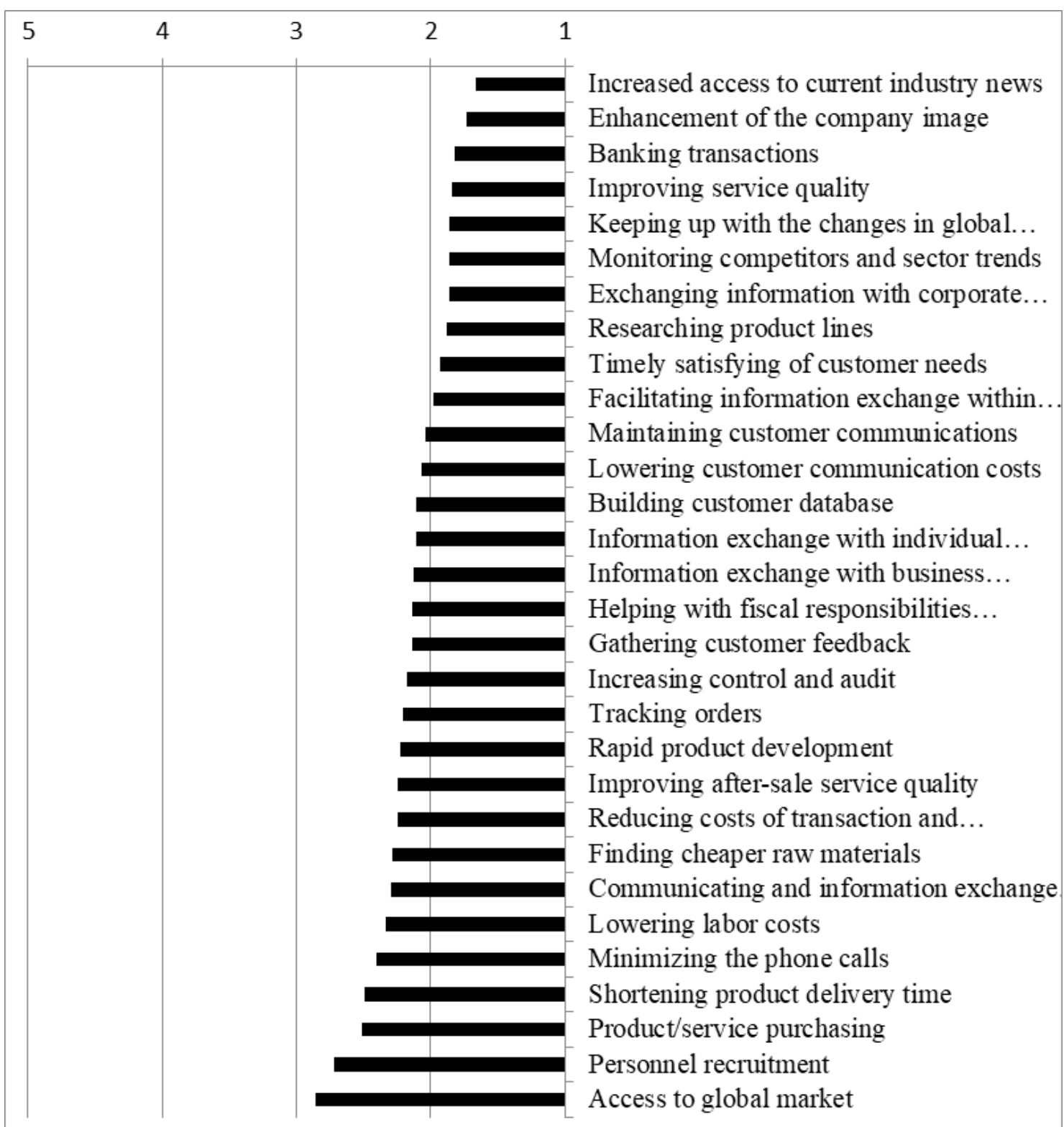

Figure 3. Perceived benefits from internet adoption 
The most important perceived benefit that the respondents would expect from the marketing of products online was related to the ability to reach out to new customers. Respondents indicated that the principal reason they would be encouraged to market products online was to gain a greater share of the market. This was followed by the desire to create increased revenue from sales. Respondents indicated that they felt market pressure was a reason to adopt e-marketing. Respondents also perceived online product marketing as a byproduct of the contemporary management perspective.

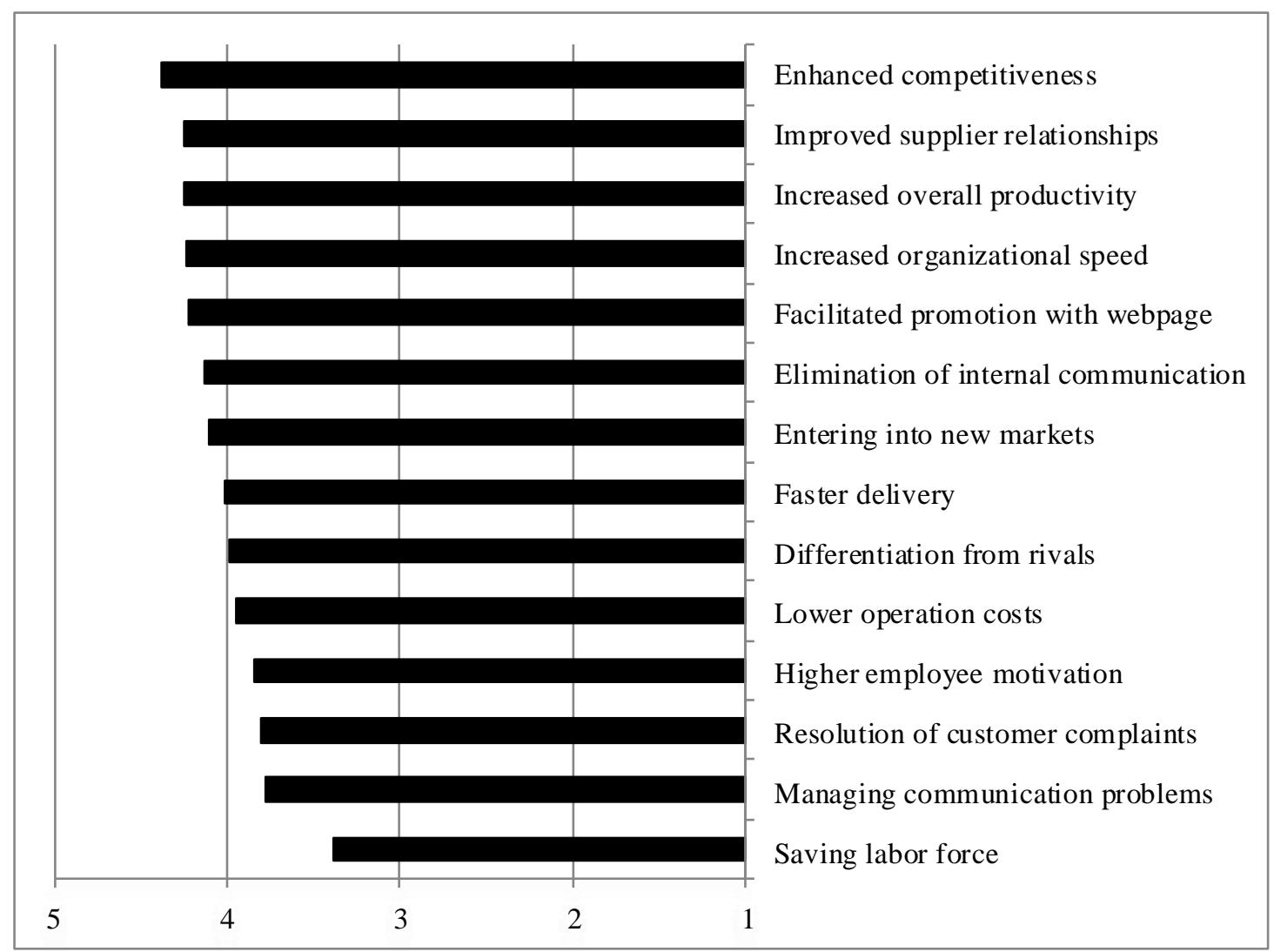

Figure 4. Ratings of features and services ICT could provide for respondent companies

Respondents were asked to evaluate the features and services ICT could provide for companies. On a 5 -point scale $(1=$ not desirable at all; $5=$ very desirable), the contribution of ICT to the competitiveness of the company ranked as the greatest incentive (Figure 4). Companies in Turkey have been facing intensified competition as a result of the growth of e-commerce (Gökmen, 2012). The value of domestic e-commerce transactions has grown from 9.2 bn $€$ in 2009 to 34.6 bn $€$ in 2014 , resulting in a compound annual growth rate of $39 \%$ (BKM, 2014). Improved relationships with suppliers, increased productivity and organizational speed, facilitating promotion, mitigating internal communication problems, and entering new markets were other important incentives for ICT use. Using the mean scores from the two-tail t-tests, all features and services ICT could provide for companies were found to be significantly different from the neutral point (3.0) of the 5point scale at the 0.05 level of significance.

\section{Conclusions}

This study achieved the objectives of exploring the adoption of ICT and the current and potential ICT uses in forest products companies in a particular region of Turkey. Based on the perceptions of the respondents, an attempt was made to investigate the underlying factors affecting the adoption of 
the ICT through factor analysis of questionnaire responses.

The three major constructs of the factors, based on the purposes of ICT use, were business productivity, information exchange and customer communications. The business productivity construct illustrated that lower labor costs, faster product delivery, increased control and audit and an enhanced image were among the important determinants of ICT use in the forest products companies. Other operational effectiveness factors in the productivity construct included improved service quality, product development, order tracking, procurement of cheaper inputs, facilitated information exchange within the company and the meeting of fiscal responsibilities.

The information exchange construct also had a significant impact on ICT use for effective management. Factors that emerged in this construct included timely satisfying of customer needs, exchanging information with corporate and individual customers and monitoring competitors and sector trends. The variables relevant to enhanced communication with customers emerged as the third construct and were designated as consumer communication. Lowering customer communication costs, gathering customer feedback and maintaining customer communications were the variables that met the significant factor loading criteria.

The most important benefits of ICT that were reported by the survey respondents were enhanced competitiveness, supplier relationships, overall business productivity and organizational speed. Some other benefits that forest products companies could expect from ICT applications were related to marketing management, such as facilitated promotion, entry into new markets, faster delivery, and resolution of customer complaints.

These findings have confirmed those of previous studies indicating that companies in the forest products industry have been slower than others in investing in and implementing ICT. Moreover, larger companies as well as exporting and younger enterprises were more likely to adopt ICT. Information and communication applications were more common than the use of e-business and e- commerce in the forest products industries covered by this study. Most of the companies surveyed had a static web page. They used email for transmitting business documents, including those for taxation, advertising, accounting and official business. Accounting was the department that exhibited the most extensive Internet use. The most important perceived incentives for Internet use in the forest products companies were increased access to current industry news, an enhanced image and facilitated banking transactions. These companies would expect to reach out to new customers through e-business applications.

As was the case with the global pioneers in the forest products industry like the USA and Canada (Hewitt et al., 2011), the forest products companies surveyed in Turkey are in the virtual and communication spaces of the evolutionary model of Internet business strategies. Most of the forest products companies in Turkey are SMEs and most do not have a competitive position in foreign trade (Müftüoğlu, 2011). In light of the decreasing trend in hardware and software prices and the emergence of new technologies, ICT could offer advantages to help small- and medium-sized forest products companies compete in the marketplace (Sowlati, 2014). The Turkish government intends to improve the ICT sector by 2023 and provides several incentives for the adoption of ICT by SMEs through the KOSGEB (Small and Medium Enterprises Development Organization) support programs. The forest products industry should plan to develop and implement ICT strategies focusing on increased business productivity, competitiveness and profits, as well as on efficient customer and supplier communications and expanded markets.

This study was conducted in only one particular region of Turkey. Therefore, the general applicability of the results across the entire forest products industry or other industries in Turkey should be taken cautiously. Further research is needed to examine the advocates, enablers and inhibitors of ICT adoption and its subsequent impact on the business performance of the forest products industry in Turkey. 


\section{References}

Angehrn, A. (1997). Designing mature internet business strategies: The ICDT model. European Management Journal, 15(4), 361369.

Arano, K. G. \& Spong, B. (2012). Electronic commerce adoption in the hardwood industry, The Journal of Extension, 50(6), 6RIB4.

BKM, (2014). Turkish interbank card center, http://www.bkm.com.tr/istatistik/kredikarti_to plam_issuer_islemleri2.asp. Accessed December $1 \overline{5}, 2014$. (in Turkish).

Cattell, R. B. (1966). The Scree test for the number of factors. Multivariate Behavior Research, 1(2), 245-276.

Dupuy, C. A. \& Vlosky, R. P. (2000). Status of electronic data interchange in the forest products industry. Forest Products Journal, $50(6), 32-38$

Field, A. (2013). Discovering Statistics Using IBM SPSS Statistics (4th ed.). London: Sage Publications.

Gökmen, A. (2012). Virtual business operations, e-commerce \& its significance and the case of Turkey: current situation and its potential. Electronic Commerce Research, 12(1), 31-51.

Hewitt, R., Sowlati, T. \& Paradi, J. C. (2011). Information technology adoption in US and Canadian forest products industries. Forest Products Journal, 61(2), 161-169.

Hutcheson, G. D. \& Sofroniou, N. (1999). The Multivariate Social Scientist: Introductory Statistics Using Generalized Linear Models. London: Sage Publications.

Kaiser, H. F. (1958). The varimax criterion for analytic rotation in factor analysis. Psychometrika, 23(3), 187-200.

Karuranga, É. Frayret, J. M. \& D’Amours, S. (2006). E-business in the Quebec forest products industry: perceptions, current uses and intentions to adopt. Journal of Forest Products Business Research, 2(4).

Kilıç, T. (2008). Use of the internet and information technology and a study on SMEs, MSc Thesis, Balıkesir University, Turkey, 107 (in Turkish, with abstract in English).

Kozak, R. A. (2002). Internet readiness and ebusiness adoption of Canadian value-added wood producers. The Forestry Chronicle, 78(2), 296-305.

Lee, J. (2004). Discriminant analysis of technology adoption behavior: A case of internet technologies in small businesses. Journal of Computer Information Systems, 44(4), 57-66.

Lemeshow, S., Hosmer, Jr. D. W., Janelle, K. \& Lwanga, S. K. (1990). Adequacy of sample size in health studies. Colchester: World Health Organization.

Levy, M. \& Powell, P. (1998). SME flexibility and the role of information systems. Small Business Economics, 11(2), 183-196.

Müftüoğlu, İ. G. (2011). Foreign trade competitiveness level of forest based sectors. MSc Thesis Düzce University, Turkey, 115, (in Turkish, with abstract in English).

Nguyen, T. H. (2009). Information technology adoption in SMEs: An integrated framework. International Journal of Entrepreneurial Behaviour \& Research, 15(2), 162-186.

OECD, (2011). OECD Guide to measuring the information society 2011. Paris: OECD Publishing.

Pitis, O. T. \& Vlosky, R. P. (2000a). Web presence of U.S. primary wood products exporters. Forest Products Journal, 50(7-8), 55-58.

Pitis, O. T. \& Vlosky, R. P. (2000b). Forest products exporting and the internet: Current use figures and implementation issues. Forest Products Journal, 50(10), 23-29.

Riquelme, H. (2002). Commercial internet adoption in china: Comparing the experience of small, medium and large businesses. Internet Research, 12(3), 276-286.

Sharma, S. (1996). Applied Multivariate Techniques. New York: John Wiley\&Sons.

Shook, S. R., Zhang, Y., Braden, R. \& Baldridge, J. (2002). The use of eBusiness in the Pacific Northwest secondary forest products industry. Forest Products Journal, 52(1), 59-66.

Sowlati, T. (2014). Current and future role of information technology in the global forest sector. In: The Global Forest Sector: Changes, Practices, and Prospects. (317340), Boca Raton, FL: CRC Press.

Stennes, B., Stonestreet, C., Wilson B. \& Wang S. (2006). E-technology adoption by value added wood processors in British Columbia. Forest Products Journal, 56(5), 24-28.

Tan, A., Baydaş, A. \& Aksen, N. (2004). Use of internet for marketing purposes by firms in Kahramanmaraş province. KSÜ Fen ve Mühendislik Dergisi, 7(2), 83-89 (in Turkish, with abstract in English).

Tinsley, H. E. \& Tinsley, D. J. (1987). Uses of factor analysis in counseling psychology research. Journal of Counseling Psychology, 34(4), 414.

TÜİK, (2014). Use of information and communication technology by enterprises, Press Release No. 16197. http://www.turkstat.gov.tr/PreHaberBultenleri .do?id=16197 Accessed December 10, 2014. 
Vlosky, R. P. (1999). eBusiness in the forest products industry. Forest Products Journal, 49(10), 12-21.

Vlosky, R. P. \& Fontenot, R. (1997). The internet and the forest products industry: Current status and projected trends. Forest Products Journal, 47(11-12), 33-40.

Vlosky, R. P. \& Gazo, R. (1996). The internet and the forest products community: The role of the forest products society. Forest Products Journal, 46(5), 19-25.
World Bank (2002). Information and Communication Technologies: A World Bank Group Strategy. Washington, D.C.: The World Bank.

Yildiz M.S. (2008). The level of utilization of information technologies in small and medium size establishments and the effect of information technologies on establishments. Elektronik Sosyal Bilimler Dergisi, 7(25), 212-239 (in Turkish, with abstract in English). 